\title{
Analisis fungsi ganda plaza pada atribut jamaah salat di Masjid Agung Jawa Tengah
}

\author{
Ahmad Mahbub Hamdani ${ }^{{ }^{*}}$, Djoko Indrosaptono ${ }^{1}$, Agung Budi Sarjono ${ }^{1}$ \\ 1. Prodi Magister Teknik Arsitektur, Fakultas Teknik, Universitas Diponegoro, Jl. Prof. Sudarto, Semarang, \\ Indonesia \\ *E-mail: arsitekmuda_emha@yahoo.co.id
}

\begin{abstract}
Analysis of multiple function of plaza in salat jamaah attributes in Masjid Agung Jawa Central. The Great Mosque of Central Java has an area called the plaza, namely Zone I, the Pillar area, and Zone II, the Payung Hidrolis Plaza Area. Preliminary observations by researchers showed that there was a suspicion related to the architectural settings of the plaza relating to the attributes of the congregation prayers, which were in the Great Mosque of Central Java. The method that will use in this research is the quantitative method using a descriptive approach. In this study, the independent variable is the perception of visitors in using the Central Java Grand Mosque plaza space with observational indicators of visitors' motivation, interests, and expectations. The dependent variable in this study is the hall attribute as a means of visitors to the main prayer room, which divided into two zones, namely: Zone I (alqonatir Pillar area) and Zone II (Hydro Payung Plaza Area). Field data collection was carried out on 300 respondents. Data collection was carried out for one week with division in 2 zones and two different times, namely afternoon and evening. Based on the results of research that has done that, there is a relationship between the function of the plaza of the Great Mosque of Central Java to the attributes of worshipers in Zone 1, Zone 2, Zone 1 and Zone 2.
\end{abstract}

Keywords: architectural setting, attributes, mosque, plaza

\section{Pendahuluan}

Indonesia adalah negara dengan jumlah penduduk muslim terbesar dunia. Berdasarkan data yang dilansir oleh Badan Pusat Statistik, penganut agama Islam di Indonesia sebesar 209,1 juta jiwa atau 87,2 persen dari total penduduk. Jumlah itu merupakan 13,1 persen dari seluruh umat muslim di dunia. Umat muslim dalam melaksanakan ibadah menggunakan bangunan masjid untuk melaksanakan aktivitas ibadah yang diperlukan. Masjid di Indonesia tersebar dimulai dari Aceh sampai dengan kepulauan maluku.

Sejarah umat islam di Indonesia tidak bisa dilepaskan dari Provinsi Jawa Tengah. Provinsi Jawa Tengah merupakan salah satu tonggak penting sejarah agama islam khususnya di Pulau Jawa. Masyarakat Jawa Tengah mayoritas penduduknya beragama Islam. Kota Semarang merupakan Ibu Kota Provinsi Jawa Tengah memiliki jumlah penduduk 31.301 .311 orang, 30.463 .360 orang $(97,36 \%)$ beragama islam. Jumlah masjid yang telah ada berjumlah 33.558 buah, sehingga setiap masjid rata-rata digunakan oleh 907 jamaah. Sedangkan di kota Semarang dengan jumlah penduduk 1.296 .024 orang, 1.089 .537 (84,07\%) beragama islam.

Masjid terbesar di Provinsi Jawa Tengah adalah Masjid Agung Jawa Tengah. Masjid Agung Jawa Tengah memiliki representasi penting terhadap umat islam di provinsi Jawa Tengah. Masjid Agung Jawa Tengah sebagai bangunan ibadah dibangun dalam gaya arsitektur campuran Jawa, Islam dan Romawi. Diarsiteki oleh Ir. H. Ahmad Fanani dari PT. Atelier Enam Jakarta yang didesain pada tahun 2001. 


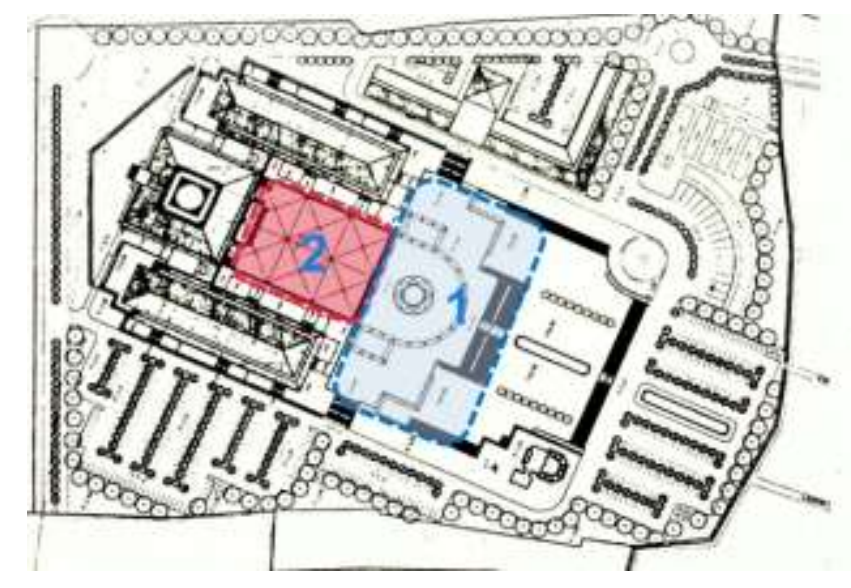

Gambar 1. llustrasi Area Plaza Masjid Agung Jawa Tengah.

(Sumber: Hasil Analisis dan Survei Primer 2019)

Menurut (Snyder \& Catanese, 1985) arsitektur berwawasan perilaku adalah arsitektur yang mampu menanggapi kebutuhan dan perasaan manusia yang menyesuaikan dengan gaya hidup manusia didalamnya. Menurut (Heimsath, 1988) kata "perilaku" menyatakan suatu kesadaran akan struktur sosial dari orang-orang, suatu gerakan bersama secara dinamik dalam waktu. Hanya dengan memikirkan suatu perilaku seseorang dalam ruang maka dapatlah kita membuat rancangan.

Peneliti telah melakukan pengamatan terkait yang akan digunakan dalam penelitian ini yang berada di Masjid Agung Jawa Tengah. Daerah yang telah dilakukan observasi biru disebut dengan plaza 1 dan plaza 2. Plaza 1 dan Plaza 2 merupakan bagian dari area Masjid Agung Jawa Tengah yang paling luas dan memiliki fungsi penting dalam setting arsitekturnya. Fenomena yang berhasil di dapatkan oleh peneliti antara lain yaitu pengujung mengalami disorientasi ruang untuk beribadah

Hal tersebut terjadi ketika pengunjung ingin melaksanakan ibadah mengalami kesusahan menemukan ruang untuk berwudu. Hal lain yang menjadi hasil amatan peneliti adalah minimnya tanda penunjuk arah atau informasi terkait dengan ruangan yang berada di area Masjid Agung Jawa Tengah. Pengunjung mengalami kebingungan untuk menemukan area yang ingin dituju. Selain hal tersebut, peneliti menemukan juga masalah yaitu keamanan atas barang bawaan pengunjung ketika berada di area Masjid Agung Jawa Tengah khususnya untuk penitipan barang dan alas kaki dari pengunjung terletak jauh agak ke dalam dan tidak terlihat langsung oleh pengunjung dari depan.

Hal tersebut menimbulkan kerawanan kehilangan barang pribadi dari pengunjung. Hasil pengamatan terakhir yang menimbulkan masalah bagi pengunjung adalah area plaza Masjid Agung Jawa Tengah kurang nyaman dilalui jika pada kondisi siang hari dikarenakan tidak memiliki penutup langsung. Penutup area tersebut hanya difungsikan jika pada acara tertentu sehingga jika tidak terdapat kepentingan maka penutup tersebut tidak difungsikan maka matahari langsung menyinari lantai dari area plaza tersebut dan menimbulkan rasa panas jika dilalui menggunakan kaki telanjang. Sedangkan area tersebut merupakan area yang tidak boleh dilewati dengan alas kaki.

Masjid Agung Jawa Tengah merupakan salah satu masjid terbesar di provinsi Jawa Tengah sehingga menarik minat masyarakat dan menjadikan jumlah kunjungannya tinggi. Pengunjung yang datang dengan berbagai variasi jumlah. Ada yang datang sendiri, bersama keluarga maupun rombongan besar. Dari hasil pengamatan tersebut bertentangan dengan teori arsitektur perilaku yang di kembangkan oleh Snyder dan Catanese sehingga peneliti berkeinginan untuk meneliti lebih lanjut terkait dengan fungsi ganda pada plaza di Masjid Agung Jawa Tengah.

\section{Metode}

Metode yang akan digunakan dalam penelitian ini adalah dengan metode kuantitatif dengan menggunakan pendekatan deskriptif, guna nilai yang terdapat pada suatu variabel tanpa membandingkan satu variabel dengan variabel yang lain. pendekatan deskriptif dilakukan untuk mendeskripsikan suatu gejala, 
peristiwa, dan kejadian yang terjadi secara faktual, sistematis, dan akurat. Metode tersebut dipilih karena dugaan ada gejala arsitektur dari plaza 1 dan plaza 2 memiliki tidak sesuai kebutuhan pengunjung yang akan melakukan ibadah. Pada penelitian ini, penulis berusaha mendeskripsikan peristiwa yang menjadi pusat penelitian tanpa memberikan perlakuan khusus terhadap peristiwa tersebut. Menurut (Sugiyono, 2013)

Dalam penelitian ini, variabel bebasnya adalah persepsi pengunjung dalam menggunakan ruang plaza Masjid Agung Jawa Tengah dengan indikator pengamatan terhadap motivasi, minat, dan harapan pengunjung. Hal tersebut dipilih karena terkait dugaan awal ada gejala arsitektur tidak sesuai dengan kebutuhan pengunjung sehingga perlu di perdalam lagi.

Sebelum pengambilan data maka kuisioner yang telah disusun diujikan kepada pengguna terlebih dahulu. Caranya yaitu dengan menyebar kuisioner kepada 20 pengunjung. Apabila kuisioner dapat $\mathrm{di}$ pahami dengan baik oleh minimal $60 \%$ responden maka kuisioner dapat diteruskan ke tahap pengambilan data lapangan.

Dalam pengambilan data lapangan dilakukan terhadap 300 responden. Hal ini sesuai dengan jumlah pengunjung rata-rata harian MAJT sekitar 3000 pengunjung, diambil 10\% (Sugiyono, 2013) maka diperoleh data sebanyak 300 responden. Data didapatkan dengan cara wawancara dengan pengelola Masjid Agung Jawa Tengah.

Variabel tergantung dalam penelitian ini adalah atribut hall sebagai sarana pengunjung menuju ruang salat utama yang dibagi dalam dua zona yaitu zona I (area Pilar alqonatir), dan zona II (Area Plaza Payung Hidrolis). Penamaan atas zona merupakan istilah yang digunakan dalam penelitian ini dengan maksud untuk memudahkan dalam mengidentifikasi area.

Pengambilan data dilakukan selama 1 minggu dengan pembagian pada 2 zona dan 2 waktu yang berbeda, sehingga data diambil dikelompokkan dalam empat kategori sampling yaitu pengambilan responden pertama di zona 1 Pukul 11.00 WIB sampai dengan 13.00 WIB sejumlah 75 responden. Pengambilan responden kedua di zona 1 Pukul 14.00 WIB sampai dengan 16.00 WIB sejumlah 75 responden. Pengambilan responden ketiga di zona 2 Pukul 11.00 WIB sampai dengan 13.00 WIB sejumlah 75 responden. Pengambilan responden keempat di zona 2 Pukul 14.00 WIB sampai dengan 16.00 WIB sejumlah 75 responden.

Pada tahap pengumpulan data, digunakan beberapa instrumen sebagai alat atau cara untuk memperoleh data. Instrumen pengumpulan data tergantung pada jenis data yang akan diperoleh. Untuk jenis data primer, digunakan kuesioner serta observasi dan dokumentasi, sedangkan untuk data sekunder, instrumen yang digunakan adalah survei lokasi, browsing internet dan mengkaji literatur.

Pada tahap analisis, diawali dengan pengelompokan hasil rekaman data dengan melakukan kategorisasi menurut bentuk persepsi yang berupa motivasi, minat dan harapan jamaah dalam menuju ruang salat utama, serta menurut macam atribut fungsi fasilitas yang berupa atribut dengan menggunakan alat bantu hitung program excel.

\section{Hasil dan Pembahasan}

\subsection{Atribut kenyamanan, atribut aksesibilitas, atribut sosiabilitas dan Keamanan di zona 1}

Hasil dari atribut kenyamanan, atribut aksesibilitas, atribut sosiabilitas dan keamanan yang muncul sesuai dengan persepsi jamaah yang berada di zona 1 dari sebanyak 150 responden. Hasil dari atribut kenyamanan pada zona 1 adalah jamaah cenderung dapat mengenali area yang terdapat pada zona 1 (72\%). Sedikit jamaah membutuhkan konsentrasi saat berada pada zona $1(26 \%)$. Kulit jamaah dominan merasa tersengat oleh panas matahari (88\%). Sedikit Jamaah merasa teduh pada zona $1(10,67 \%)$. Jamaah cenderung merasa jarak menuju ruang salat terasa jauh $(63,33 \%)$. Jamaah cenderung merasa jarak menuju tempat wudu jauh. Sesuai dengan pendapat (Julius Panero, 1979) pada sudut pandang $60^{\circ}$ pada setiap arah, akan diperoleh bayangan yang sangat tajam untuk ditransmisikan ke otak sehingga memunculkan persepsi yang dalam. Pada kondisi ruang terbuka di zona 1 seluruh bangunan sekitarnya berbentuk bangunan tinggi sehingga pengunjung akan mudah mengenali dan mengidentifikasi bentuk bangunan yang ada di sekitarnya, namun belum bisa menemukan fungsi ruang di dalam bangunan tersebut.

Zona 2 atribut aksesibilitas hasilnya adalah hanya sedikit jamaah merasa pandangan menuju ruang wudu pada zona 1 jauh tanpa halangan (40\%). Jamaah cenderung merasa jarak yang digunakan menuju 
ruang wudu pada zona 1 terasa dekat namun terhalangi (53,33\%). Jamaah cenderung merasa zona 1 tidak mudah untuk dilewati $(65,33 \%)$. Sesuai dengan pendapat (Julius Panero, 1979) pada sudut pandang $60^{\circ}$ pada setiap arah, akan diperoleh bayangan yang sangat tajam untuk ditransmisikan ke otak sehingga memunculkan persepsi yang dalam. Ketika responden belum menaiki anak tangga maka akan sudut pandangnya menjadi terbatas untuk menemukan dan mengenali ruang yang akan di tujunya terutama ruang bersuci untuk kemudian menuju ruang salat utama.

Atribut sosiabilitas dan Keamanan Jamaah cenderung merasa tidak ada gangguan yang berarti pada Zona $1(82,67 \%)$. Jamaah cenderung yakin untuk meletakan alas kaki pada batas suci yang telah ditentukan pada Zona $1(74,67 \%)$. Pada setting arsitektur di zona 1 ini, atribut sosiabilitas dan keamanan telah memenuhi atribut pengunjung hal ini di buktikan dengan beberapa kelompok ataupun individu yang melakukan kegiatan secara bersamaan tanpa saling mengganggu. Pengunjung juga meletakkan propertinya pada batas suci yang telah di tentukan

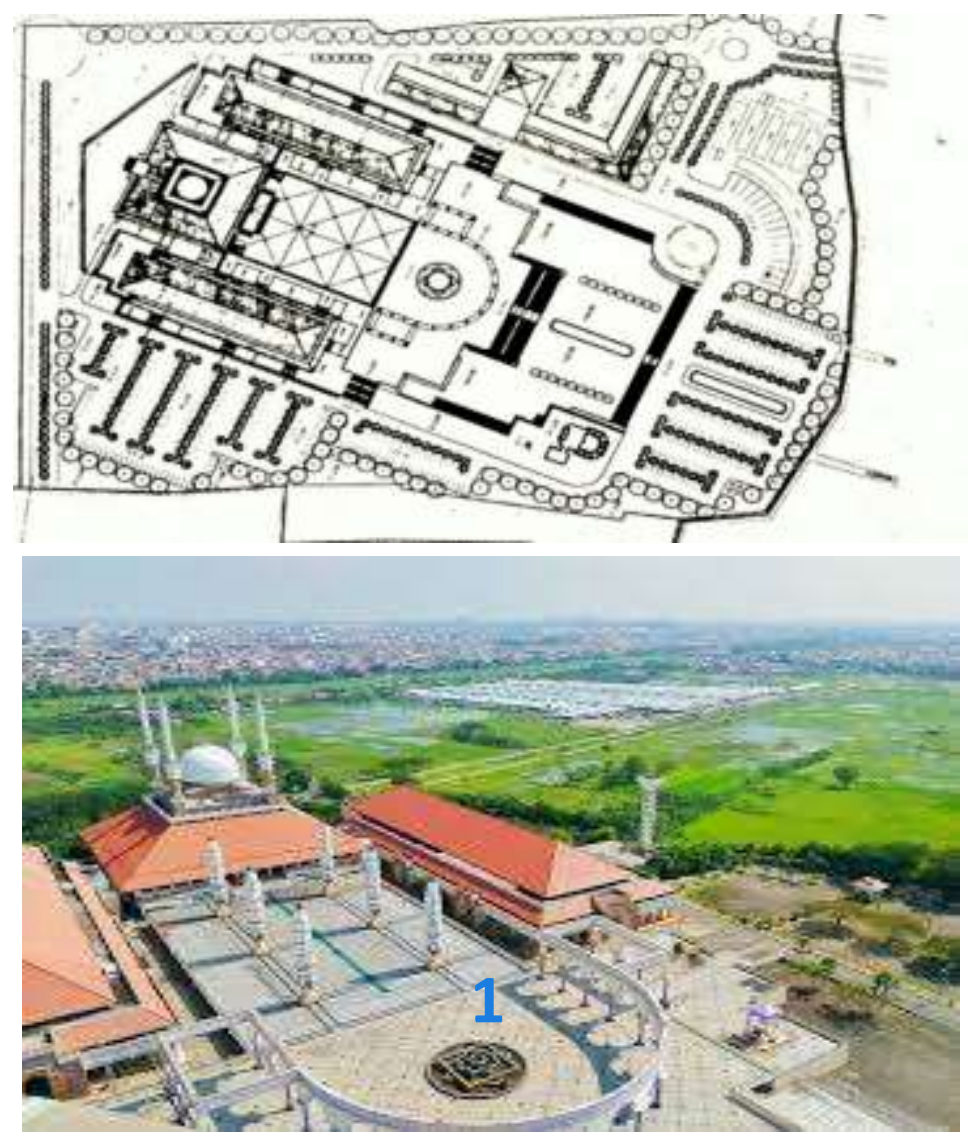

Gambar 2. Ilustrasi Area Zona 1 (Area Pilar Alqonatir) di Masjid Agung Jawa Tengah.

(Sumber: Hasil Analisis dan Survei Primer 2019)

\subsection{Atribut kenyamanan, atribut aksesibilitas, atribut sosiabilitas dan Keamanan di zona 2}

Hasil dari atribut kenyamanan, atribut aksesibilitas, atribut sosiabilitas dan keamanan yang muncul sesuai dengan persepsi jamaah yang berada di zona 2 dari sebanyak 150 responden adalah atribut kenyamanan di zona 2 yaitu jamaah cenderung dapat mengenali area yang terdapat pada zona $2(53,33 \%)$. Sebagian Jamaah membutuhkan konsentrasi saat berada pada zona $2(40,67 \%)$. Kulit jamaah dominan merasa tersengat oleh panas matahari (88\%). Sedikit sekali jamaah merasa teduh pada zona $2(5,33 \%)$. Jamaah cenderung merasa jarak menuju ruang salat terasa jauh $(56,67 \%)$. Jamaah cenderung merasa jarak menuju tempat wudu jauh (50\%). Mengacu pada pendapat (Budiharjo, 1992) ruang terbuka adalah bagian dari ruang yang memiliki definisi sebagai wadah yang menampung aktivitas manusia dalam suatu lingkungan yang tidak mempunyai penutup dalam bentuk fisik. Di antara fungsi ruang terbuka adalah sebagai sarana 
penghubung antara suatu tempat dengan tempat yang lain dan sebagai pembatas atau jarak di antara bangunan.

Atribut aksesibilitas di zona 2 adalah sebagian jamaah merasa pandangan menuju ruang wudu pada zona 2 jauh tanpa halangan (46\%). Sebagian jamaah cenderung merasa jarak yang digunakan menuju ruang wudu pada zona 2 terasa dekat namun terhalangi (43\%). Jamaah cenderung merasa zona 2 tidak mudah untuk dilewati $(60,67 \%)$. Artinya dapat diasumsikan bahwa pengunjung merasa dekat untuk menuju ke ruang wudu ketika berada pada zona 2, namun kesulitan untuk menemukannya. Sedangkan permasalahan aksesibilitas pengunjung pada zona yang paling banyak adalah pengunjung merasakan bahwa zona 2 sulit dilewati. Hal ini dikarenakan oleh bayangan material yang terkesan licin sehingga dikhawatirkan akan melukai pengunjung atau mengakibatkan pengunjung terjatuh. Akibatnya pengunjung akan berjalan dengan cepat dengan konsentrasi yang tinggi.

Atribut sosiabilitas dan keamanan di zona 2 adalah jamaah cenderung merasa tidak ada gangguan yang berarti pada zona $2(85,33 \%)$. Jamaah cenderung yakin untuk meletakan alas kaki pada batas suci yang telah ditentukan pada zona $2(62,67 \%)$. Hanya sedikit pengunjung yang merasa tidak aman dalam meninggalkan propertinya pada batas yang telah ditentukan. Dampaknya tidak patuh sebagian pengguna ini, mereka meletakkan properti mereka pada tempat-tempat yang tidak selayaknya sehingga menimbulkan tidak rapi atau tidak bagus.

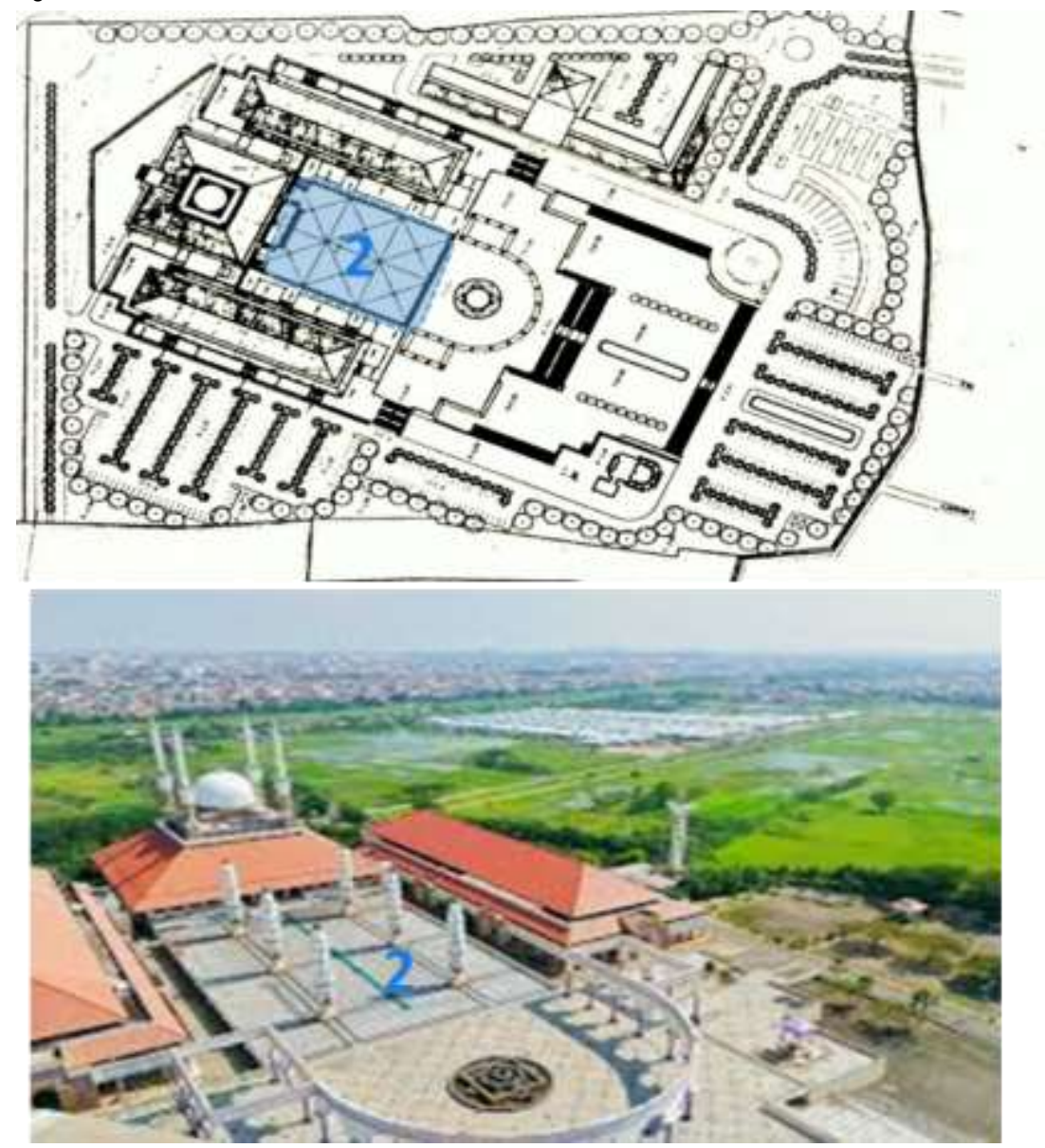

Gambar 3. Ilustrasi Area Zona 2 (Hall berpayung hirdrolis) Masjid Agung Jawa Tengah. (Sumber: Hasil Analisis dan Survei Primer 2019).

\subsection{Atribut kenyamanan, atribut aksesibilitas, atribut sosiabilitas dan Keamanan di Zona 1 dan Zona 2}

Hasil dari atribut kenyamanan, atribut aksesibilitas, atribut sosiabilitas dan keamanan yang muncul sesuai dengan persepsi jamaah yang berada di zona 1 dan zona 2 dari sebanyak 300. Atribut Kenyamanan 
yang ada di zona 1 dan zona 2 adalah jamaah cenderung dapat mengenali area yang terdapat pada zona 1 dan zona $2(62,67 \%)$. Sedikit Jamaah membutuhkan konsentrasi saat berada pada zona 1 dan zona 2 $(33,33 \%)$. Kulit jamaah dominan merasa tersengat oleh panas matahari $(88 \%)$. Sedikit sekali Jamaah yang merasa teduh pada zona 1 dan zona $2(8 \%)$. Jamaah cenderung merasa jarak menuju ruang salat terasa jauh (60\%). Jamaah cenderung merasa jarak menuju tempat wudu jauh (54,33\%).

Secara umum setting ruang pada area plaza baik zona 1 (pilar alqonatir) maupun Zona 2 (Plaza payung) dapat memenuhi atribut kenyamanan pengguna untuk dapat mengenali dengan cepat dan mudah fungsi ruang pada kedua zona tersebut. Hal ini dinyatakan dengan sebanyak $62,67 \%$ responden menyatakan dapat mengenali dengan mudah lingkungan plaza dan pilar alqonatir tersebut. Sesuai dengan pendapat (Julius Panero, 1979) pada sudut pandang $60^{\circ}$ pada setiap arah, akan diperoleh bayangan yang sangat tajam untuk ditransmisikan ke otak sehingga memunculkan persepsi yang dalam. Ruang plaza tidak memenuhi atribut pengguna yaitu memenuhi kenyamanan pada indra peraba, $88 \%$ pengguna menyatakan panas oleh terpaan sinar matahari dan radiasi lantai. Hal ini dikarenakan pada kedua ruang tersebut tidak terdapat atap permanen dan lantai granitile yang menyerap panas matahari. Hal tersebut sesuai dengan ilustrasi berikut.

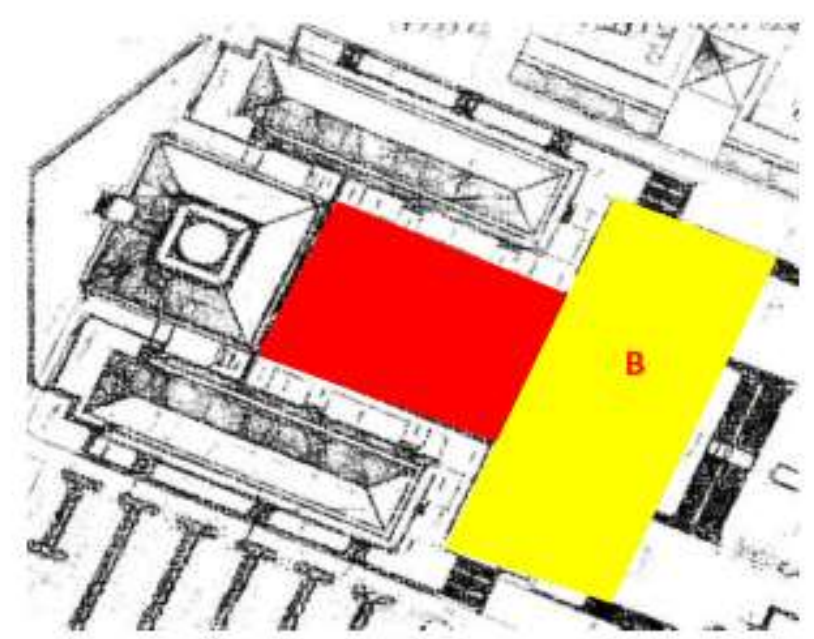

Gambar 4. Lokasi plaza yang dirasakan panas oleh pengunjung. Keterangan gambar $\mathrm{A}$ area harus melepas alas kaki. Keterangan gambar $B$ boleh menggunakan alas kaki.

(Sumber: Hasil Analisis dan Survei Primer 2019).

Atap payung hidrolik pada ruang plaza juga dibuka hanya pada hari-hari dan momen tertentu saja. Setting arsitektur pada zona 1 dan zona 2 sebagai ruang terbuka sebagai plaza menurut (Moughtin, 2003), square atau plaza adalah sebuah area yang dikelilingi oleh bangunan-bangunan dan area yang dirancang untuk memamerkan kemegahan suatu bangunan. Serta menurut (Marcus \& Francis, 1997), berdasarkan bentuk dan fungsinya Plaza pada zona 1 Masjid Agung Jawa Termasuk dalam Corporate Foyer adalah bagian dari kompleks bangunan-bangunan tinggi, fungsi utamanya adalah untuk memberikan daya tarik seperti pintu masuk yang elegan dan citra dari perusahaan bersangkutan. Plaza sebagai akses menuju ruang salat utama maupun tepat wudu dirasakan oleh pengguna terlalu jauh. Dampak terhadap ini pengguna bisa merasakan kelelahan. $60 \%$ pengguna menyatakan akses menuju ruang salat utama dengan jarak 50 $200 \mathrm{M}$ dirasakan jauh. begitu juga akses menuju ruang wudu oleh $54,33 \%$ pengguna juga menyatakan merasa jauh. Hal tersebut sesuai dengan ilustrasi berikut. 


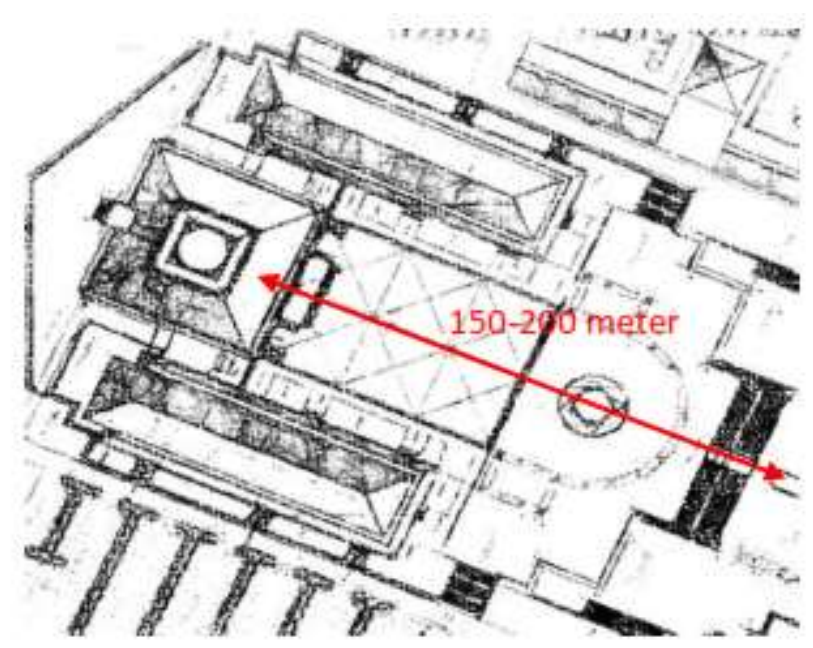

Gambar 5. Jarak ujung plaza menuju ruang salat utama.

(Sumber: Hasil Analisis dan Survei Primer 2019).

Hal ini sesuai dengan teori yang dikemukakan oleh Michael Jones (Priyomarsono, 1999) bahwa sirkulasi manusia dalam kaitannya dengan kemudahan dapat diartikan kelayakan lebar minimum $90 \mathrm{~cm}$ dan jarak capai tidak lebih dari $60 \mathrm{~m}$. Selain itu juga harus memperhatikan kelancaran sirkulasi dalam arti tidak menyulitkan pemakai, tidak berliku-liku dan tidak membahayakan, apabila melebihi hal tersebut maka akan dirasakan melelahkan oleh umumnya pengguna. Dampak dari setting ini adalah jamaah memilih melewati jalur kendaraan bermotor untuk menemukan jarak yang lebih pendek untuk menuju ke ruang wudu dan ruang salat utama.

Atribut aksesibilitas yang ada di zona 1 dan zona 2 adalah jamaah cenderung merasa pandangan menuju ruang wudu pada zona 1 dan zona 2 jauh tanpa halangan (43\%). Jamaah cenderung merasa jarak yang digunakan menuju ruang wudu pada zona 1 dan zona 2 terasa dekat namun terhalangi $(48,33 \%)$. Jamaah cenderung merasa zona 1 dan zona 2 tidak mudah untuk dilewati (63\%). Sebanyak 48\% pengunjung menyatakan kesulitan menemukan uang wudu, hal ini karena posisi ruang wudu yang sulit diketahui dan harus berjalan memutar untuk menemukannya, sedangkan akses menuju ruang wudu dan ruang salat utama tersebut menurut $63,00 \%$ pengunjung merasakan sulit untuk dilewati, karena membahayakan bagi keselamatan pengunjung, yakni lantai yang licin dan panas radiasi lantai.. Hal ini juga yang membatasi sudut pandang jamaah untuk menemukan ruang-ruang pendukung di sekitar Masjid Agung Jawa Tengah. Sesuai dengan teori (Julius Panero, 1979) pada sudut pandang $60^{\circ}$ pada setiap arah, akan diperoleh bayangan yang sangat tajam untuk ditransmisikan ke otak sehingga memunculkan persepsi yang dalam. Ketika jamaah belum menaiki anak tangga maka akan sudut pandangnya menjadi terbatas untuk menemukan dan mengenali ruang yang akan di tujunya terutama ruang bersuci untuk kemudian menuju ruang salat utama.

Minimnya tanda pengarah juga menjadikan pengunjung merasa kesulitan untuk menemukan ruang wudu yang berada di lantai dasar Masjid Agung Jawa Tengah. Padahal dalam masjid terdapat ruang-ruang inti yang merupakan ruang utama pada sebuah masjid, yaitu ruang salat, ruang untuk bersuci dan beranda. Terlepas dari kategori dari masjid yang bersangkutan sebab masjid diharuskan memiliki ruang-ruang inti tersebut. Ruang salat merupakan ruang utama pada masjid yang terdiri dari mihrab dan ruang Jemaah. Ruang bersuci (wudu) merupakan tempat yang tidak terpisahkan dari keberadaan suatu masjid. Teras atau beranda berfungsi untuk menjaga kebersihan dan kesucian ruang salat (Susanta, Gatut; Amin, Choirul; Kautsar, 2007)

Menurut (Budiharjo, 1992) salah satu fungsi ruang terbuka adalah Sebagai sarana penghubung antara suatu tempat dengan tempat yang lain. zona 1 berfungsi sebagai penghubung antara lokasi parkir dengan tempat wudu atau bersuci bagi jamaah yang akan melaksanakan ibadah. Dikarenakan kesulitan 
menemukan ruang ini maka fungsi ini pada zona 1 tidak dapat terpenuhi. Seperti yang di deskripsikan pada gambar 4.47, di mana pengunjung dari tempat parkir akan jalan turun menuju ruang wudu kemudian akan naik lagi menuju ruang salat utama. Proses ini bisa menempuh jarak kurang lebih $500 \mathrm{~m}$. Jadi permasalahan pada zona dalam mencapai ruang wudu adalah jarak sebenarnya tidak jauh namun terhalangi sehingga alurnya menjadi berliku sehingga menjadikan jaraknya menjadi jauh. Kaitan dengan teori yang dikemukakan oleh (Wijayanti, 2000) visibilitas yaitu dengan "jarak" yang dirasakan oleh manusia. Jarak yang dirasakan bukan hanya jarak yang dirasakan secara dimensional atau geometris saja, tetapi menyangkut persepsi visual di mana seseorang merasa ada tidaknya halangan untuk mencapai obyek yang.

Atribut sosiabilitas dan keamanan yang ada di zona 1 dan zona 2 adalah jamaah cenderung merasa tidak ada gangguan yang berarti pada zona 1 dan zona $2(84 \%)$. Jamaah cenderung yakin untuk meletakan alas kaki pada batas suci yang telah ditentukan pada zona 1 dan zona $2(68,67 \%)$. Atribut sosiabilitas dan keamanan pada zona 1 terpenuhi dengan baik, hal ini dinyatakan dengan $84,00 \%$ pengguna tidak merasakan terganggu apabila ada orang atau kelompok lain beraktivitas di sebelahnya. Begitu juga mengenai keamanan $68,67 \%$ pengguna menyatakan merasa aman untuk meletakkan properti miliknya pada batas-batas yang telah ditentukan. Pada setting arsitektur di zona 1 ini, atribut sosiabilitas dan keamanan telah memenuhi atribut pengunjung hal ini di buktikan dengan beberapa kelompok ataupun individu yang melakukan kegiatan secara bersamaan tanpa saling mengganggu. Pengunjung juga meletakkan propertinya pada batas suci yang telah di tentukan.

\section{Simpulan}

Dapat disimpulkan berdasarkan penelitian yang telah dilakukan bahwa secara nyata ada hubungan fungsi plaza Masjid Agung Jawa Tengah terhadap atribut jamaah salat pada zona 1, zona 2, zona 1 dan zona 2. Atribut yang dihasilkan dari respons jamaah pada zona 1 adalah pada atribut kenyamanan setting ruang pada zona 1 mudah dikenali jamaah, zona 1 terasa panas oleh paparan matahari dan radiasi lantai, dan arah menuju ruang salat utama dan tempat bersuci terlalu jauh. Atribut aksesibilitas pada zona 1 adalah ruang wudu dan kamar mandi dekat namun terhalangi, untuk menuju ruang tersebut harus melalui alur sirkulasi yang berbelit dan zona 1 tidak mudah dilewati atau membahayakan pengguna. Atribut sosiabilitas dan keamanan adalah setting ruang cukup memberikan rasa aman dan privasi terlindungi.

Atribut yang dihasilkan dari respon jamaan pada zona 2 adalah pada atribut kenyamanan setting ruang pada zona 2 mudah dikenali jamaah, zona 2 terasa panas oleh paparan matahari dan radiasi lantai, dan jarak menuju ruang salat utama dan Tempat bersuci/wudlu terlalu jauh. Atribut aksesibilitas pada zona 2 adalah zona 2 tidak mudah dilewati atau membahayakan pengguna. Atribut sosiabilitas dan keamanan pada zona 2 adalah setting ruang cukup memberikan rasa aman dan privasi terlindungi.

Atribut yang dihasilkan dari respon jamaah pada zona 1 dan zona 2 secara berurutan dapat disimpulkan atribut kenyamanan adalah setting ruang pada zona 1 dan zona 2 mudah dikenali jamaah, zona 1 dan zona 2 terasa panas oleh paparan matahari dan radiasi lantai, jarak menuju ruang salat utama dan tempat bersuci/wudlu terlalu jauh. Atribut aksesibilitas pada zona 1 dan zona 2 ruang adalah wudlu/kamar mandi dekat namun terhalangi, untuk menuju ruang tersebut harus melalui alur sirkulasi yang berbelit, dan zona 1 dan zona 2 sebagai penghubung tidak mudah dilewati atau membahayakan pengguna. Atribut sosiabilitas dan keamanan pada zona 1 dan zona 2 adalah setting ruang cukup memberikan rasa aman dan privasi terlindungi

Kondisi dan persepsi pengunjung/jamaah pada Masjid Agung Jawa Tengah adalah pengunjung Masjid Agung Jawa Tengah mayoritas adalah jamaah domestik yang berasal dari luar kota semarang, jamaah yang menggunakan plaza pada Masjid Agung Jawa Tengah jumlahnya hampir seimbang antara lakilaki dan perempuan, minat pengunjung masjid Agung Jawa Tengah, paling banyak adalah setelah datang bisa menemukan ruang bersuci (wudlu) dan kamar mandi, setelah itu melanjutkan menuju ruang ibadah utama, harapan pengunjung pada Masjid Agung Jawa Tengah menginginkan adanya perubahan setting arsitektur pada Plaza Masjid Agung supaya disesuaikan dan memenuhi kebutuhan atribut jamaah, rasa minat pengunjung pada Masjid Agung Jawa Tengah adalah merasakan teduh selama melewati ruang plaza, namun hal ini justru sebaliknya jamaah merasakan panas matahari ketika melewati ruang plaza yang berada 
pada Masjid Agung Jawa Tengah. Pada rasa minat lain persepsi pengunjung untuk mendapatkan kemudahan sirkulasi dan keamanan terlindungi dapat terpenuhi.

\section{Daftar Pustaka}

Budiharjo, E. (1992). Sejumlah masalah permukiman kota. https://doi.org/10.1002/zaac.201300446

Heimsath, C. (1988). Arsitektur dari segi perilaku: menuju proses perancangan yang dapat dijelaskan. https://doi.org/10.1002/zaac.201300446

Julius Panero. (1979). Dimensi Manusia \& Ruang Interior. https://doi.org/10.1002/zaac.201300446

Marcus, C. C., \& Francis, C. (1997). People places: design guidelines for urban open space (2 edition; C. F. Clare Cooper Marcus, Ed.). California: John Wiley \& Sons,.

Moughtin, C. (2003). Urban design : street and square. Oxford: Architectural Press.

Priyomarsono, N. W. (1999). Tinjauan Konsep Bangunan Jawa (Sebuah Kajian Literatur). Jurnal Kajian Teknologi, 1(1), 1-20. https://doi.org/10.1017/CB09781107415324.004

Snyder, J. C., \& Catanese, A. J. (1985). Pengantar Arsitektur. Jakarta: Erlangga.

Sugiyono. (2013). Metode Penelitian Pendidikan Pendekatan Kuantitaif, Kualitatif, dan R\&D. In Metode Penelitian Pendidikan Pendekatan Kuantitaif, Kualitatif, dan R\&D. https://doi.org/10.1007/s13398-0140173-7.2

Susanta, Gatut; Amin, Choirul; Kautsar, R. (2007). Membangun Masjid dan Mushola. https://doi.org/10.1002/zaac.201300446

Wijayanti, S. (2000). POLA SETING RUANG KOMUNAL INTERAKSI SOSIAL MAHASISWA Studi Kasus Jurusan Arsitektur Fakultas Teknik UNDIP (Universitas Diponegoro). Retrieved from http://eprints.undip.ac.id/11585/ 